\title{
A NEW SPECIES OF CLEISTES (VANILLOIDEAE, ORCHIDACEAE) FROM COLOMBIA
}

\author{
Dariusz L. SzlachetKo \& Marta KolanowsKa ${ }^{1}$
}

\begin{abstract}
A new species of Cleistes Lindl., C. lehmannii is described and illustrated based on Colombian material. The taxonomic affinities of the new entity are briefly discussed. The species is placed within a key to identification of the national representatives of the genus.
\end{abstract}

Key words: Cleistes, Neotropics, new species, Orchidaceae, taxonomy

Dariusz L. Szlachetko \& Marta Kolanowska, Department of Plant Taxonomy and Nature Conservation, University of Gdańsk, Wita Stwosza 59,80-308 Gdańsk, Poland; e-mail: martakolanowska@wp.pl

\section{INTRODUCTION}

The Neotropical genus Cleistes was described in 1818 by Richard and validated by Lindley in 1840 , but its taxonomic separateness was called into question for years by many authors who placed species of the genus in Pogonia Juss. (e.g., Schweinfurth 1958; Schultes 1960; Williams et al. 1980). The latter genus is currently recognized as comprising only about three species (Brown 2005), one known from eastern North America and two from East Asia. The two genera may be distinguished mainly by lip ornamentation and flower arrangement. The lip disc of Cleistes is always furnished with longitudinal crests with two clavate, basal projections on each side and/or short fleshy hairs. The inflorescence has two or more flowers. Unlike Cleistes, the inflorescence of Pogonia usually is single-flowered and the lip is densely patterned with long fleshy hairs. Moreover, Cleistes species produce root tubers, which are lacking in Pogonia. The morphological differences, complemented by results from molecular studies, confirm the separateness of the two genera (Cameron \& Chase 1999).

As currently recognized, species of Cleistes are characterized by the presence of sessile cauline

1 Corresponding author leaves which are remotely arranged along the stout stem. The flowers, loosely arranged in the inflorescence, are supported by large leafy bracts. The flowers are resupinate, usually large, showy and ephemeral, often lasting one day. The sepals and petals typically are similar in shape, but the latter usually are wider and shorter. The lip is sessile, with paired stipitate processes at the base. The erect, slender, clavate gynostemium generally is more or less sigmoid (Szlachetko \& Rutkowski 2000).

Cleistes comprises over 50 species distributed from Argentina to Costa Rica, with a single taxon native to the southeastern USA [C. divaricata (L.) Ames]. Usually they are found at lower elevations growing in moist, sandy, lateritic, acid soils, usually in open savanna, in the ecotone between savanna and forest, in undergrowth, sometimes along roadsides, and occasionally in forest.

Up to 2007 six species had been reported from Colombia by Ortiz Valdivieso \& Uribe Vélez (2007), but those authors adopted the broad concept of $C$. rosea Lindl. and they embedded within this species $C$. venusta (Schltr.) Schltr. and C. $a b$ dita G. A. Romero \& Carnevali. The latest research by Szlachetko and Baranow (2012) revealed the existence of four more species in Columbia. 
While examining Colombian materials of Orchidaceae housed in the Herbarium of the Natural History Museum in Vienna (W) we came across a specimen of an unknown species of Cleistes. Fritz W. L. Kränzlin's handwritten name Pogonia lehmannii was attached to the herbarium sheet. He never published this name (ICN Art. 29.1, McNeill et al. 2012); The complete description, illustrations and notes on the taxonomic affinities of the new species are presented in this paper.

\section{DESCRIPTION OF THE NEW SPECIES}

Cleistes lehmannii Kraenzl. ex Szlach. \& Kolan., sp. nov.

Fig. 1

This species appears to be related to Cleistes rosea Lindl., from which it differs by its exceptionally long, long-acuminate lateral sepals, much exceeding the length of the lip, petals and dorsal sepal, and by the lip whose upper margins are crenulate, the disc bearing two lamellae running along the total lip length, which on the apical part are crispate on the margins.

Holotype: COLOMBIA, Dept. Valle del Cauca, Rio Dagua, Lehmann 752 (W).

Vegetatively this species is very similar to C. rosea. Floral bracts up to $c a 13 \mathrm{~cm}$ long, leafy. Pedicellate ovary to $40 \mathrm{~mm}$ long, slender. Dorsal

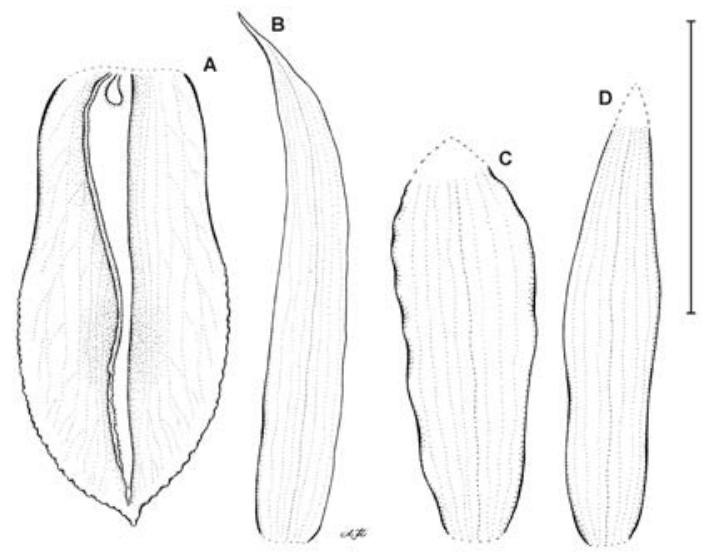

Fig. 1. Cleistes lehmanni Kraenzl. ex Szlach. \& Kolan., sp. nov. A - lip, B - lateral sepal, C - petal, D - dorsal sepal. Scale bar $=30 \mathrm{~mm}$. Drawn by A. Król from holotype.

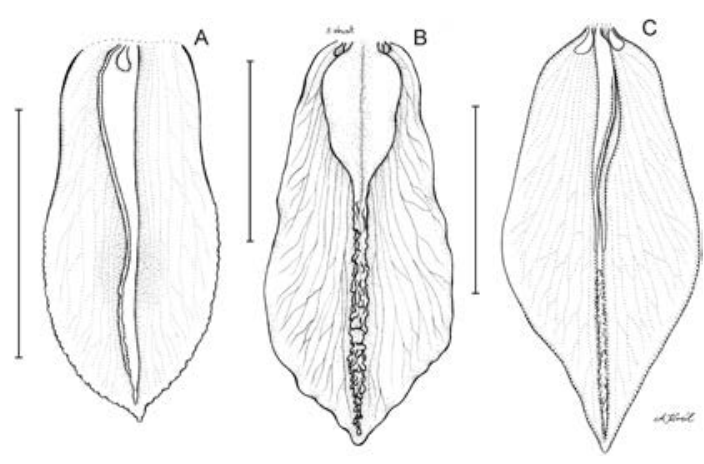

Fig. 2. Comparison of lip shapes of A - Cleistes lehmanni Kraenzl. ex Szlach. \& Kolan., sp. nov. (Lehmann 752, W), B - C. abdita G. A. Romero \& Carnevali, (Garcia Barriga et al. 15842, COL) and C - C. rosea Lindl. (Lehmann 1302, $\mathrm{K})$. Scale bars $=30 \mathrm{~mm}$. Drawn by A. Król and S. Nowak.

sepal $4.8 \mathrm{~cm}$ long and $9 \mathrm{~mm}$ wide, oblong-lanceolate, acuminate, acute at apex, 7-veined, margin entire. Lateral sepals $5.5 \mathrm{~cm}$ long and $8 \mathrm{~mm}$ wide, linear-lanceolate, apex long-acuminate, upcurved, 7-veined, margin entire. Petals $4.3 \mathrm{~cm}$ long and $13.5 \mathrm{~mm}$ wide, oblong-subspatulate, apex subobtuse, 9-veined, apical margin undulate. Lip $4.7 \mathrm{~cm}$ long and $20 \mathrm{~mm}$ wide, tubular in natural position, oblong elliptic when expanded, concave, shortly acuminate at apex, apical margin slightly crenulate; disc with two lamellae running from base up to lip apex, lamellae crispate on margins in apical part, lip base with two clavate projections partially covered with lamellae. Gynostemium $2.7 \mathrm{~cm}$ long.

Distribution. So far the species is known exclusively from the Pacific region of southwestern Colombia, Department of Valle del Cauca.

Notes. In its habit and the vegetative characters the new species resembles $C$. rosea Lindl. widespread from Costa Rica to Brazil and Bolivia, as well as C. abdita G. A. Romero \& Carnevali known from Venezuela and Colombia. Cleistes lehmanni is easily distinguished from those two species by its long lateral sepals which are much longer than other perianth segments. In its two congeners, $C$. rosea and $C$. abdita, the lip is longer than the sepals and petals. Unlike its relatives, the new species is characterized by long-acuminate lateral sepals, whereas they are subobtuse in C. abdita 
and short-acuminate in C. rosea. Other differences between the three species are observed in their lip apical margins, which are crenulate in C. lehmanni and entire in C. abdita and C. rosea (Fig. 2).

\section{Key to the Colombian sPecies of CLeistes}

1. Lip unlobed, elliptic or oblong-elliptic, more or less attenuate towards apex .............. 2

1. Lip distinctly 3-lobed, divided into hypochile and epichile ..................... 9

2. Lip linear-oblong in outline $\ldots \ldots \ldots \ldots 3$

2. Lip elliptic to trullate in outline . .......4

3. Lip obscurely 3-lobed, callus consisting of two lamellae at lip base only, glandular hairs in middle and lacinate, transverse lamellae at apex ..........

C. munchiquensis Szlach. \& Baranow

3. Lip unlobed, callus consisting of single lamella in central part of lip, with erose margin .......... .......... C. tenuis (Rchb. f. ex Griseb.) Schltr.

4. Lip callus consisting of two lamellae disappearing in center of lamina or transforming into erose thickening(s) $\ldots \ldots \ldots \ldots \ldots \ldots \ldots \ldots$

4. Lip callus consisting of two lamellae much higher in basal half than in apical half . . . . . . . 7

5. Lip elliptic, two lamellae disappearing near center of lamina . . . . . . . . . . . . . . . . . . . .

C. triflora (C. Schweinf.) Carnevali \& I. Ramírez

5. Lip trullate, two lamellae transforming into erose thickening(s) ................ 6

6. Lip widest just above middle, lamellae oblonglinear when flattened and spread, basal clavate callosities prominent ........ . rosea Lindl.

6. Lip widest below apex, lamellae obtrullate-obovate when spread and flattened, basal callosities very obscure ... C. abdita G. A. Romero \& Carnevali

7. Lip oblong-pandurate in outline, lamellae shorter near middle than above and below ............. .... . C. lehmannii Kraenzl. ex Szlach. \& Kolan.

7. Lip oblong-elliptic in outline, lamellae not as above ................... 8

8. Lip acuminate at apex, anther's filament with entire margins ....... C. acuminata (Schltr.) Schltr.

8. Lip acute at apex, anther's filament with crenulate margins . . . . . . C. venusta (Schltr.) Schltr.

9. Hypochile obovate-obtriangular, margins erose above middle, epichile distinctly wider than long, transversely elliptic, truncate $\ldots \ldots \ldots \ldots \ldots \ldots$. ........... C. idroboi Szlach. \& Baranow
9. Hypochile oblong or oblong-elliptic, margins entire, epichile longer than wide, oblong . ....... 10

10. Petals with entire margins, apex of hypochile more or less cordate .............. 11

10 . Petals with erose margins, apex of hypochile truncate or obtuse ............. 12

11. Hypochile with 3 lamellae running from base to apex .......... C. elegantula (Schltr.) Schltr.

11. Hypochile with oblong, papillate callus running to

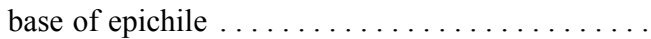
......... C. moritzii (Rchb. f.) Garay \& Dunst.

12. Hypochile with erose apical margins, massive callus densely puberulent above basal third, epichile long-clawed ................. .......... . uribei Szlach. \& Baranow

12 . Hypochile with entire margins, callus consisting of two lamellae running from its base almost to apex, edges of lamellae lacinate, epichile oblongligulate ... C. risaraldensis Szlach. \& Baranow

ACKNOWLEDGEMENTS. We are grateful to the Curator and staff of the Herbarium of the Natural History Museum in Vienna for their kind hospitality and assistance during visits, the anonymous reviewers for helpful remarks on the manuscript, and Anna Król and Sławomir Nowak for preparing the illustrations. This paper is part of a project supported by a grant from the Polish Ministry of Science and Higher Education (3930/PO1/2007/33).

\section{REFERENCES}

Brown P. M. 2005. Wild orchids of Florida. Press of Florida University, Gainesville.

Cameron K. 2003. Cleistes. In: A. Pridgeon, P. Cribb, M. W. Chase \& F. N. RASMussen (eds), Genera Orchidacearum. Orchidoideae. 2. Vanilloideae, pp. 286-289. Oxford University Press, Oxford.

Cameron K. M. \& Chase M. W. 1999. Phylogenetic relationships of Pogoniinae (Vanilloideae, Orchidaceae): an herbaceous example of the eastern North America-eastern Asia phytogeographic disjunction. J. Pl. Res. 112: 317-329.

LindLEY J. 1840. The genera and species of Orchidaceous plants. Ridgways, London.

McNeill J., Barrie F. R., Buck W. R., Demoulin V., Greuter W., Hawksworth D. L., Herendeen P. S., Knapp S., Marhold K., Prado J., Prud'homme van Reine W. F., Smith G. F., Weirsema J. H. \& TuRLAND N. J. 2012. International Code of Nomenclature for algae, fungi, and plants (Melbourne Code). Regnum Veg. 154: [i]-xxx, 1-208. 
Ortiz Valdivieso P. \& Uribe Vélez C. 2007. Galería de Orquídeas de Colombia (CD edition). Asociación Bogotana de Orquideología, Bogotá.

RICHARD L. C. M. 1818. De Orchideis Europaeis Annotationes. Mém. Mus. Hist. Nat. 4: 23-61.

Schultes R. E. 1960. Native Orchids of Trinidad and Tobago. Pergamon, London.

SchweInfurth C. 1958: Orchidaceae, Orchids of Peru. Fieldiana, Bot. 30(1): 1-260.
Szlachetko D. L. \& Baranow P. 2012. Four new species of Cleistes (Orchidaceae, Vanilloideae) from Colombia. Ann. Bot. Fenn. 49: 377-382.

Szlachetko D. L. \& Rutkowski P. 2000. Gynostemia Orchidalium. 1. Apostasiaceae, Cypripediaceae, Orchidaceae (Thelymitroideae to Vanilloideae). Acta Bot. Fenn. 169: 308 .

Williams L. O., Allen P. H. \& Dressler R. L. 1980. Orchids of Panama: A facsimile reprint of the Orchidaceae, flora of Panama. Missouri Botanical Garden Press, St. Louis.

Received 8 October 2013 